\title{
Pengaruh Kepemimpinan Terhadap Kinerja Anggota Reserse Polresta Pekanbaru
}

\author{
AZNURIYANDI \\ Fakultas Ekonomi Universitas Lancang Kuning \\ Jn. Yos Sudarso KM 8 Rumbai \\ E-mail : aznuriyandi@unilak.ac.id
}

\begin{abstract}
This research was conducted in Pekanbaru City Police Reserve Unit Jalan Ahmad Yani No. 11 Pekanbaru-Riau. The purposeof this study is Knowing Leadership Influenceon Performance Pekanbaru Police Detective Member. While the benefit soft his research is as consideration in applying the provision of leadership in improving the performance of Pekanbaru Police Detective Member on the future. Data collection techniques used in this research is to use the data collection tool in the form of questionnaires and interviews, and the sampling method used is random sampling by the formula Slovin. Where the amount of the overall population of 156 people and a sample of 88 people. Analysis of the data used is a simple linear regression analysis with SPSS vers. 17. Besides done also partial test ( $t$ test). From the results of research on the influence of leadership in improving the performance of members of disatlantas pekanbaru tcount $t \neg \neg$ tabel ie greater than 8365> 1,999. Leadership means having a significant effect in improving the performance of members of Traffic pekanbaru. Large influence the dependent variable can be seen from the value of coefficient of determination ( $R$-square), the amount is 0.449 or $44.9 \%$, while the remaining $55.1 \%$ is influenced by other independent variables were not examined in this study.influenced by other independent variables were not examined in this study
\end{abstract}

\section{Keywords: Leadership, Performance}

Indonesia untuk menjadi negara yang sedang berkembang yang dipersiapkan untuk menjadi negara yang diperhitungkan di Asia. Organisasi pada umumnya percaya bahwa untuk mencapai keunggulan harus mengusahakan kinerja individual yang setinggi-tingginya, karena pada dasarnya kinerja individual mempengaruhi kinerja tim atau kelompok kerja dan pada akhirnya mempengaruhi kinerja organisasi secara keseluruhan. Namun dalam kenyataan seharihari, kinerja tinggi bagi pegawai bukanlah hal yang mudah untuk dicapai. Banyak hal yang menghalangi seorang pegawai mencapai kinerja tinggi tersebut.

Kepolisian Republik Indonesia merupakan salah satu institusi di Indonesia yang mempekerjakan pegawai dalam jumlah sangat besar. Institusi ini menyerap tenaga kerja yang memiliki berbagai kemampuan dan bidang keahlian dengan tingkat pendidikan yang beragam. Seperti halnya sebuah institusi, Kepolisian Republik Indonesia sebagai sebuah organisasi juga membutuhkan inovasi untuk meningkatkan profesionalisme dalam melindungi dan melayani masyarakat. Kurangnya ide-ide kreatif bagi kemajuan organisasi, mendorong organisasi pada pertumbuhan yang stagnan, sehingga menurunkan profesionalisme anggota organisasi. Salah satu cara untuk mengembalikan organisasi pada kinerja yang tinggi adalah dengan Kepemimpinan berperan yang berkembang dalam organisasi.

Kepolisian Negara Republik Indonesia (Polri) merupakan organisasi publik atau pemerintah yang dalam perjalanan sejarahnya cukup lama berada dalam sistem organisasi militer. Sistem organisasi militer telah mewarisi dan menanamkan nilai-nilai fragmatis dan terstruktur dalam pengelolaan sumber daya manusianya, meskipun saat ini Polri telah melakukan reformasi di dalam organisasinya. Hal ini menjadi menarik ketika budaya organisasi yang masih feodal dan fragmatis telah melahirkan dan membentuk kepemimpinan yang otoriter dalam diri pemimpin Polri. 
Kepemimpinan mempunyai peran penting dalam peningkatan kualitas kinerja anggota dalam menjalankan tugasnya. Adapun penilaian kinerja yang dilaksanakan anggota ini dapat dilihat pada pencapaian hasil dalam menyelesaikan setiap kasus yang ada, Untuk itu dapat kita lihat data lima tahun terakhir terhadap penyelesaian kasus dilihat pada tabel berikut ini:

\begin{tabular}{|c|c|c|c|c|}
\hline Tabel 1 & $\begin{array}{l}\mathrm{Pe} \\
\mathrm{Ke} \\
\mathrm{Pe}\end{array}$ & $\begin{array}{l}\text { elesaian } \\
\text { olisian di } \\
\text { nbaru tahur }\end{array}$ & $\begin{array}{l}\text { Kasus } \\
\text { Reserse }\end{array}$ & $\begin{array}{l}\text { Anggota } \\
\text { Polresta }\end{array}$ \\
\hline Tahun & $\begin{array}{c}\text { Jumlah } \\
\text { kasus }\end{array}$ & $\begin{array}{c}\text { Kasus yang } \\
\text { terselesaikan }\end{array}$ & \begin{tabular}{|c|}
$\begin{array}{c}\text { kasus yang } \\
\text { belum } \\
\text { selesai }\end{array}$ \\
\end{tabular} & $\begin{array}{l}\text { Persentase } \\
\quad(\%)\end{array}$ \\
\hline 2009 & 1256 & 1123 & 133 & $10,59 \%$ \\
\hline 2010 & 1278 & 1135 & 143 & $11,19 \%$ \\
\hline 2011 & 1342 & 1157 & 185 & $13,79 \%$ \\
\hline 2012 & 1398 & 1187 & 211 & $15,09 \%$ \\
\hline 13 & 1450 & 1123 & 327 & o \\
\hline
\end{tabular}

Dari tabel dapat diketahui bahwa Kinerja kerja anggota kepolisian pada Reserse Polresta Pekanbaru untuk lima tahun terakhir menunjukkan penurunan. dapat kita lihat puncak tertinggi dari absensi anggota terjadi pada tahun 2014 sebesar $(22,55 \%)$. Tingginya tingkat kasus yang belum terselesaikan ini menandakan Pemimpin belum optimal dalam mengarahkan anggota dalam menjalankan tugasnya sehingga kinerja yang dihasilkan belum maximal.

Dalam mencapai tujuan organisasi kepemimpinan juga mempunyai peran dalam menggerakkan anggota. Kepemimpinan adalah kemampuan untuk mempengaruhi suatu kelompok untuk pencapaian tujuan. Berdasarkan hasil wawancara yang dilakukan oleh peneliti kepada anggota angkasa pura mengenai kepemimpinan:

1. Membangun Hubungan, seorang pemimpin haruslah membangun hubungan baik dengan para bawahan dan ataupun rekan kerja lainnya. berdasarkan wawancara yang dilakukan peneliti menyimpulkan dalam membangun hubungan, masih belum berjalan secara baik karena belum tercapainya tujuan yang ditetapkan oleh pemimpin, sehingga kinerja yang dihasilkan anggota masih belum optimal.

2. Mencari dan Memberi Informasi, seorang pemimpin adalah panutan bawahan melaksanakan pekerjaan. Karenanya, seorang pemimpin harus memiliki kemampuan memonitor, menjelaskan dan menginformasikan berbagai hal kerja kepada bawahannya. berdasarkan wawancara yang dilakukan peneliti menyimpulkan komunikasi antar anggota belum dapat dijalankan dengan lancar. Hal itu terlihat dari seringnya terlambatnya laporan pertanggungjawaban pekerjaan dari masing-masing pekerjaan kekantor pusat.

3. Membuat Keputusan, seorang pemimpin bukan sekedar memimpin, tetapi berwenang memutuskan sesuatu. Karenanya, seorang pemimpin harus mampu merencanakan, memecahkan masalah, berkonsultasi, dan mendelegasikan wewenang dan tanggung-jawab. berdasarkan wawancara yang dilakukan peneliti menyimpulkan masih sering terlambatnya pimpinan dalam menentukan keputusan sehingga membuat terhambatnya prosedur kerja yang telah direncanakan, sehingga mempengaruhi kinerja anggota.

4. Mempengaruhi Orang lain, seorang pemimpin harus mampu menggerakan bawahan untuk melaksanakan pekerjaan dengan sebaik-baiknya untuk mencapai tujuan organisasi. Karenanya, seorang pemimpin harus memiliki kemampuan meKepemimpinan, mengakui, dan memberi imbalan sesuai dengan apa yang dikerjakan oleh anggotanya tersebut.

Berdasarkan permasalahan yang telah diuraikan diatas, maka penulis tertarik untuk mengadakan serangkaian kegiatan penelitian dengan judul "Pengaruh 
Kepemimpinan terhadap Kinerja Anggota Reserse Polresta Pekanbaru".

Amstrong \& Baron dalam Wibowo (2011:7) mengemukakan kinerja merupakan hasil pekerjaan yang mempunyai hubungan kuat dengan tujuan strategis organisasi, kepuasan konsumen, dan memberikan kontribusi pada ekonomi. Dengan demikian, kinerja adalah tentang apa yang dikerjakan dan bagaimana cara mengerjakannya.

Dalam kondisi pembangunan yang kompetitif dan mengglobal sekarang ini Institusi memerlukan pegawai yang dapat menunjukkan kinerja (Job Performance) yang tinggi. Mathis-jackson (2006:378) mengartikan bahwa kinerja pada dasarnya adalah apa yang dilakukan dan tidak dilakukan oleh anggota. Kinerja anggota tersebut pada umumnya untuk kebanyakan pekerjaan meliputi elemen sebagai berikut: a. Kuantitas dari hasil, b. Kualitas dari hasil, c. Ketetapan waktu dari hasil, d. Kehadiran, e. Kemampuan bekerja sama. Menurut Bernadin dalam Robbins (2006:260), penilaian kinerja pegawai secara individual dapat dilakukan dengan menggunakan enam kriteria, yaitu:

a. Kualitas; tingkat pencapaian hasil aktivitas yang dilakukan mendekati sempurna. Dengan kata lain dapat menyesuaikan beberapa cara ideal dari penampilan aktivitas ataupun memenuhi tujuan yang diharapkan dari suatu aktivitas.

b. Kuantitas; jumlah yang dihasilkan dinyatakan dalam istilah seperti unit, program, atau jumlah siklus aktivitas yang diselesaikan.

c. Ketepatan waktu; tingkat suatu aktivitas diselesaikan pada waktu awal yang diinginkan, dilihat dari sudut koordinasi dengan hasil out put serta memaksimalkan waktu yang tersedia untuk aktivitas yang lain.

d. Efektivitas; tingkat penggunaan sumber daya organisasi dimaksimalkan dengan maksud menaikkan keuntungan atau mengurangi kerugian dari setiap unit dalam penggunaan sumber daya. e. Kemandirian; tingkat pencapaian seorang pegawai dalam melakukan fungsi kerjanya tanpa meminta bantuan atau bimbingan dari pengawas.

f. Komitmen kerja; tingkat kesungguhan pegawai dalam berkomitmen untuk kerja dan bertanggung jawab dalam pekerjaannya.

Menurut Hasibuan (2007:170)

kepemimpinan adalah cara seorang pemimpin mempengaruhi perilaku bawahan, agar mau bekerja sama dan bekerja secara produktif untuk mencapai tujuan organisasi. Kepemimpinan menurut Isyandi (2004:149) adalah kemampuan memperoleh konsensus dan keikatan pada sasaran bersama, melalui syarat-syarat organisasi yang dicapai dengan sumbangan pengalaman dan kepuasan di pihak kelompok kerja. Lebih lanjut Isyandi mengungkapkan, secara garis besar definisi kepemimpinan mengacu pada tiga hal, yaitu:

1. Memberikan penekanan kepada kepribadian, kemampuan dan kesanggupan pemimpin;

2. Memberikan penekanan pada kegiatan, kedudukan dan perilaku pemimpin;

3. Memberikan penekanan pada proses interaksi antara pemimpin, bawahan dalam situasi tertentu.

Machasin \& andreas (2005:74) mengungkapkan, bahwa hakikat dari kepemimpinan adalah kemampuan mempengaruhi sifat dan perilaku anggota yang berbeda-beda ke arah tujuan yang sama. Sementara itu Rivai (2009:58-59) dalam hal kepemimpinan menjelaskan istilah self-leadership dan superleadership. Self-leadership adalah apa yang orang lakukan untuk memimpin diri mereka sendiri. Mengembangkan setiap orang untuk menjadi self-leadership yang efektif adalah tantangan yang menarik dan berat. Pemimpin yang melakukan ini disebut Superleadership. Lebih spesifik, seorang superleadership adalah seseorang yang memimpin orang lain untuk memimpin diri mereka sendiri. 
Kepemimpinan adalah sebagai proses mengarahkan dan memengaruhi aktifitas yang berkaitan dengan tugas dari para anggota kelompok (yulk,1994 dalam edy sutrisno (2011:218)

Pada dasarnya, terdapat perbedaan tipis antara istilah pemimpin dan manajer (Thoha, 2009:261-263). Namun demikian, realitanya dapat kita saksikan secara nyata. "Manajer" mensyaratkan adanya organisasi. Sementara "Pemimpin" bisa berada diluar konteks organisasi. Sehingga aktivitas manajemen terlihat mengalir melalui alur struktural, sementara kepemimpinan melalui alur sosial. Kepemimpinan bisa terjadi kapanpun dan dimanapun. Ketika terdapat upaya mempengaruhi perilaku orang lain, maka dikatakan terdapat fenomena kepemimpinan ketika itu. Oleh karenanya, kepemimpinan dalam birokrasi lebih sering dikaitkan dengan manajerialisme.

Kouzes \& Posner (1995:25-64) dalam penelitiannya menemukan lima praktik mendasar kepemimpinan teladan atau berkualitas unggul, yakni : (1) pemimpin yang menantang proses, (2) mengilhamkan wawasan bersama, (3) memungkinkan orang lain dapat bertindak, (4) menjadi penunjuk jalan, dan (5) mendorong hati.

Yukl et al dalam edy sutrisno (2011:218), menyebutkan empat taksonomi integrasi perilaku kepemimpinan yang efektif, sebagai berikut :

1. Membangun hubungan

Dalam hal ini, seorang pemimpin haruslah membangun hubungan baik dengan para bawahan dan ataupun rekan kerja lainnya. Hal ini ditunjukkan dengan sikap/perilaku pemimpin yang selalu memberikan dukungan kepada anggota. Seorang pimpinan juga harus memberikan perhatian untuk mengembangkan kemampuan bawahan, memberikan bimbingan, berupaya membangun tim, mengelola konflik dengan sebaik-baiknya, serta terus-menerus berupaya untuk membentuk/membangun jaringan.

Hal di atas menggambarkan, bahwa seorang pemimpin dalam membangun hubungan dengan cara berkomunikasi bukan hanya dilingkungan internal, tetapi juga dengan pihak eksternal organisasi. Hal ini sebagaimana dikemukakan oleh Siagian (2003:55), bahwa pemeliharaan hubungan baik ke luar maupun ke dalam dilakukan melalui proses komunikasi, baik secara lisan maupun secara tertulis.

Artinya, peranan seorang pimpinan bukan sekedar koordinasi, tetapi yang teramat penting adalah mengintegrasikan berbagai kegiatan yang diselenggarakan berbagai satuan kerja organisasi. Hal ini dimaksudkan agar tercapai tingkat efisiensi, efektivitas dan produktivitas yang diinginkan dan ditetapkan, sekaligus menemukan berbagai cara mengatasi berbagai permasalahan, penyimpangan dan penyelewengan yang mungkin timbul. Integrasi demikian hanya mungkin terwujud jika pimpinan dalam organisasi mampu menjalankan komunikasi yang efektif (Siagian, 2003:7).

2. Mencari dan memberi informasi

Seorang pemimpin adalah panutan bawahan, yang mengilhami bawahaan melaksanakan pekerjaan. Karenanya, seorang pemimpin harus memiliki kemampuan memonitor, menjelaskan dan menginformasikan berbagai hal kerja kepada bawahannya.

Siagian (2003:20) menjelaskan, efektivitas kepemimpinan seseorang juga sangat ditentukan oleh kemampuannya mengenali secara tepat sifat kondisi yang dihadapinya, baik kondisi yang terdapat dalam organisasi maupun diluar organisasi, yang berdampak pada jalannya roda organisasi. Untuk dapat memonitor, menjelaskan dan menginformasikan berbagai hal kerja kepada bawahannya, maka seoring pemimpin harus memiliki sifat yang inkuisitif. Siagian (2003:84) mengemukakan, bahwa sifat inkuisitif atau rasa ingin tahun merupakan suatu sikap yang mencerminkan (1) tidak merasa puas dengan tingkat pengetahuan yang dimiliki, dan (2) kemauan dan keinginan untuk mencari dan menemukan hal-hal baru.

Dengan adanya sifat inkuisitif dimaksud, maka pemimpin dapat 
melaksanakan tugas kepemimpinannya secara efektif, terutama dalam hal memonitor pelaksanaan kerja bawahan, menjelaskan pekerjaan, dan menginformasikan berbagai hal yang terkait dengan pelaksanaan pekerjaan, untuk mencapai tujuan organisasi.

3. Membuat keputusan

Seorang pemimpin bukan sekedar memimpin, tetapi berwenang memutuskan sesuatu. Karenanya, seorang pemimpin harus mampu merencanakan, memecahkan masalah, berkonsultasi, dan mendelegasikan wewenang dan tanggung-jawab.

Siagian (2003:46) menjelaskan

dimana telah diakui secara luas, bahwa kemampuan mengambil keputusan merupakan salah satu kriteria efektivitas kepemimpinan seseorang. Bahkan kemampuan mengambil keputusan dewasa ini pada umumnya diterima sebagai inti kepemimpinan. Hal ini berdasarkan penelitian dari banyak ilmuwan dan pengalaman para praktisi menunjukkan, bahwa efektivitas kepemimpinan seseorang pada akhirnya dinilai dengan menggunakan kemampuan mengambil keputusan sebagai kriteria utamanya. Namun, kemampuan mengambil keputusan tidak terutama diukur dengan ukuran kuantitatif, dalam arti jumlah keputusan yang diambil, tetapi seberapa jauh jumlah keputusan yang diambil bersifat praktis, realistik dan dapat dilaksanakan serta memperlancar usaha pencapaian tujuan organisasi.

Hal ini memberikan gambaran, bahwa suatu keputusan yang diambil haruslah berkualitas. Suatu keputusan yang berkualitas hanya dapat diambil oleh seorang pemimpin dengan kepemimpinan yang berkualitas.

4. Mempengaruhi orang lain

Seorang pemimpin harus mampu menggerakkan bawahan untuk melaksanakan pekerjaan dengan sebaik-baiknya untuk mencapai tujuan organisasi. Karenanya, seorang pemimpin harus memiliki kemampuan memotivasi, mengakui, dan memberi imbalan.

Seorang pemimpin berada dalam organisasinya adalah untuk mengintegrasikan berbagai potensi sumber daya organisasi untuk bersinergi menjadi suatu kekuatan dalam pencapaian tujuan organisasi. Kepemimpinannya diharapkan dapat memacu motivasi para anggotanya, dapat memberikan pengakuan atas peran anggotanya, serta dapat memberikan imbalan sesuai dengan prinsip-prinsip keadilan yang dianut organisasi.

Berdasarkan kajian teori dan permasalahan penelitian, maka dalam penelitian ini penulis merumuskan hipotesis sebagai berikut: "Diduga bahwa Kepemimpinan berpengaruh terhadap Kinerja Anggota Reserse Polresta Kota Pekanbaru."

Tabel 1Defenisi Konsep dan Operasional Variabel Penelitian

\begin{tabular}{|c|c|}
\hline Definisi Variabel & Indikator \\
\hline $\begin{array}{l}\text { Kinerja (Y) } \\
\text { Kinerja adalah merupakan } \\
\text { hasil pekerjaan yang } \\
\text { mempunyai hubungan } \\
\text { kuat dengan tujuan } \\
\text { strategis organisasi, } \\
\text { kepuasan konsumen, dan } \\
\text { memberikan kontribusi } \\
\text { pada ekonomi. (Amstrong } \\
\& \text { Baron dalam Wibowo } \\
(2011: 7)\end{array}$ & 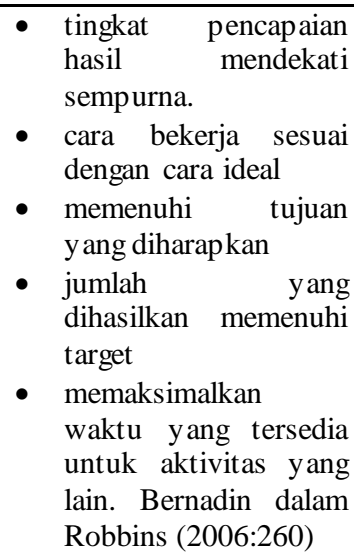 \\
\hline $\begin{array}{lr}\text { Kepemimpinan } & (\mathrm{X}), \\
\text { adalah sebagai } & \text { proses } \\
\text { mengarahkan } & \text { dan } \\
\text { memengaruhi } & \text { aktifitas } \\
\text { yang berkaitan } & \text { dengan } \\
\text { tugas dari para anggota } & \text { ango } \\
\text { kelompok } & \text { (yulk,1994 } \\
\text { dalam edy } & \text { sutrisno } \\
(2011: 218) & \end{array}$ & $\begin{array}{ll}\text { - Upaya membangun } \\
\text { tim kerja y ang solid } \\
\text { - Upaya mengelola } \\
\text { konflik } \\
\text { - Upaya mencari } \\
\text { informasi y ang dapat } \\
\text { mempelancar segala } \\
\text { aktivitas kerja } \\
\text { Kemauan \& } \\
\text { kemampuan } \\
\text { memutuskan } \\
\text { pemecahan masalah } \\
\text { Kemampuan } \\
\text { memotivasi kerja } \\
\text { karyawan. Yukl et } \\
\text { al.(1994) dalam edy } \\
\text { sutrisno (2011:218) }\end{array}$ \\
\hline
\end{tabular}

\section{METODE}

Lokasi penelitian yang dilakukan oleh penulis yaitu Polresta Kota Pekanbaru Unit Reserse Jalan Ahmad Yani No. 11 Pekanbaru-Riau. 
dari :

Data-data yang akan penulis peroleh

a. Data Primer

Pada penelitian ini data primer yaitu data yang dikumpulkan dan diperoleh melalui pengamatan langsung di lokasi penelitian dengan mengambil data yang dibutuhkan sesuai dengan penelitian yaitu berupa tanya jawab langsung dengan Anggota Reserse Polresta Kota Pekanbaru yang akan diteliti, dan melalui quisioner yang sebagai bahan untuk mengetahui permasalahan dalam penelitian ini.

b. Data Sekunder

Pada penelitian ini data sekunder ini adalah data yang diperoleh dari Institusi dalam bentuk yang sudah siap disusun atau diolah, dapat berbentuk tabel atau laporan-laporan lainnya. Seperti sejarah singkat Institusi, aktifitas Institusi, struktur organisasi Institusi serta fungsi atau tugas masing-masing bidang kerja dalam Institusi. Sumber data di peroleh dari Reserse Polresta Kota Pekanbaru.

Adapun teknik yang digunakan dalam usaha pengumpulan data pada penelitian ini adalah sebagai berikut :

1. Wawancara / Interview

Yaitu cara mengumpulkan data dengan cara melakukan wawancara secara langsung baik dengan Anggota Reserse Polresta Kota Pekanbaru, mengenai hal-hal yang erat hubungannya dengan permasalahan yang menjadi objek penelitian ini..

2. Angket Quistionery.

Yaitu data didapat dengan cara membuat daftar pertanyaan kepada responden untuk memperoleh data yang dibutuhkan, dalam hal ini Reserse Polresta Kota Pekanbaru.

1. Populasi

Populasi adalah keseluruhan objek penelitian sebagai sumber data yang memiliki karakteristik dalam suatu penelitian.

Dalam penelitian ini yang merupakan populasi adalah seluruh anggota Reserse
Polresta Kota Pekanbaru yang berjumlah 156 orang anggota.

2. Sampel

Sampel adalah bagian dari populasi yang menjadi sumber data sebenarnya dalam suatu penelitian. Pada penelitian ini penulis menggunakan metode pengambilan sampel secara random sampling terhadap populasi yang ada. Besarnya jumlah sampel digunakan rumus sebagai berikut: (Sugiono, 2008):

$\mathrm{n}=\frac{\mathrm{N}}{1+N \mathrm{e}^{2}}$

Dimana :

$$
\mathrm{n}=\text { Jumlah sampel }
$$$$
\mathrm{N}=\text { Jumlah populasi (156 }
$$

jumlah anggota tahun 2012)

$$
N=\text { error }(10 \%)
$$

Maka banyaknya sampel yang diambil adalah :

$$
\begin{aligned}
n & =\frac{156}{1+156 \times 5 \%^{2}} \\
n & =\frac{156}{1+156 \times 0.005} \\
& =87,64 \text { orang dibulatkan menjadi } 88
\end{aligned}
$$
orang

Dalam menganalisis data penulis menggunakan metode kualitatif (deskriptif) dan kuantitatif:

1. Analisis Deskriptif

Metode deskriptif adalah penganalisaan data melalui metode merumuskan, menguraikan dan menginterprestasikan berdasarkan telaah pustaka yang terdapat dalam skripsi dan literatur sebagai referensi penelitian ini untuk kemudian ditarik sebuah kesimpulan.

2. Metode Kuantitatif

Untuk mengukur pengaruh variabel bebas (Kemimpinan) dan variabel terikat (Kinerja) akan digunakan metode analisis regresi linear sederhana dengan merumuskan sebagai berikut:

$$
\mathrm{Y}=\mathrm{a}+\mathrm{bX}+\mathrm{e}
$$

Dimana : $Y=$ (Variabel Dependent) Kinerja

$$
\begin{aligned}
& \mathrm{a}=\text { Konstanta } \\
& \mathrm{X}=\text { (Variabel Independent) }
\end{aligned}
$$

Kepemimpinan 


$$
\begin{aligned}
& \mathrm{e}=\text { Kesalahan sampel } \\
& \mathrm{b}=\text { Koefisien regresi }
\end{aligned}
$$

Metode Analisis data yang digunakan dalam penelitian ini adalah Skala Likert. Skala likert digunakan untuk mengukur sikap, pendapat dan persepsi seseorang atau kelompok orang tentang fenomena sosial. Skor jawaban responden dalam penelitian terdiri atas 5 alternatif jawaban yang mengandung variasi nilai bertingkat. (Sugiono, 2008:133).dimana responden diminta untuk menjawab dengan nilai jawaban sebagai berikut, yaitu:

1. Apabila jawaban Sangat Baik diberi skor 5

2. Apabila jawaban Baik diberi skor 4

3. Apabila jawaban Cukup Baik diberi skor 3

4. Apabila jawaban Kurang Baik diberi skor 2

5. Apabila jawaban Sangat Kurang Baik diberi skor 1

Dalam mengukur penilaian per responden menjawab mengenai seluruh item pernyataan variabel yang telah diberi bobot, setelah dilakukan tabulasi terhadap hasil perhitungan masing-masing variabel pada kuesioner yang disebarkan 88 orang responden maka data-data tersebut diproses dengan menggunakan program SPSS (Statistical Product and Service Solution) versi 17.

\section{a. Uji t (Parsial)}

Uji $\mathrm{t}$ digunakan untuk menguji apakah secara parsial, variabel bebas mempunyai pengaruh yang signifikan atau tidak signifikan terhadap variabel terikat, Pengujian dilakukan melalui $t$ dengan membandingkan $\mathrm{t}$ hitung dengan $\mathrm{t}$ tabel pada $\alpha=0,05$. (Suharyadi dan Purwanto, 2009:228).

Apabila hasil pengujian menunjukkan :
a) $t_{h} \geq t_{t}$
Artinya : Variabel bebas dapat menerangkan variabel terikatnya, dan ada pengaruh diantara dua variabel yang di uji.

$$
\text { b) } t_{h} \leq t_{t}
$$

Artinya : Variabel bebas tidak dapat menerangkan variabel terikatnya, dan tidak ada pengaruh diantara dua variabel yang di uji.

b. Uji Koefisien Determinasi $\left(R^{2}\right)$

Koefisien Determinasi $\left(R^{2}\right)$ pada intinya digunakan untuk mengukur seberapa jauh kemampuan model dalam menerangkan variabel terikat. Koefisien determinasi $\left(R^{2}\right)$ mempunyai range antara 0 sampai $1\left(0<R^{2}<1\right)$. Semakin besar nilai $R^{2}$ (mendekati 1) maka berarti pengaruh variabel bebas secara serentak dianggap kuat dan apabila $\left(R^{2}\right)$ mendekati nol (0) maka pengaruh variabel bebas terhadap variabel terikat serentak adalah lemah.

\section{HASIL}

Untuk mengetahui pengaruh

Kepemimpinan Terhadap Kinerja Reserse Polresta Pekanbaru dalam penelitian ini peneliti menggunakan data dari hasil kuesioner, model yang digunakan dalam penelitian ini adalah analisis regresi sederhana dan uji $\mathrm{t}$ yaitu membandingkan antara t-Tabel dan t-hitung.

Dari hasil perhitungan analisis regresi sederhana dengan menggunakan proses SPSS Vers. 17.0 diperoleh hasil sebagai berikut:

\begin{tabular}{|l|c|c|c|}
\hline Variabel & Koefisien Regresi & $t_{\text {hiutng }}$ & Probabilitas \\
\hline Konstanta & 5.338 & 4.330 & 0,000 \\
\hline Kepemimpinan & 0,649 & 8.365 & 0,000 \\
\hline $\begin{array}{l}\mathrm{r}=0,670 \% \\
\mathrm{r}^{2} \text { Square }=44,9 \% \\
\text { Adjusted } \mathrm{R}=44,2 \%\end{array} \quad$ Probabilitas $=0,000$ \\
\\
Sumber : Hasil Olahan SPSS
\end{tabular}

Berdasarkan Tabel diatas maka

dapat diperoleh persamaan regresi sebagai berikut:

$$
\mathrm{Y}=\mathrm{a}+\mathrm{bX}
$$

$$
\text { Maka } Y=5.338+0,649 X
$$

Keterangan:

$\mathrm{Y}=$ Kinerja

$\mathrm{a}=$ Konstanta

$\mathrm{b}=$ Koefisien regresi variabel independent

$\mathrm{X}=$ Kepemimpinan 
Polresta Pekanbaru (Aznuriyandi)

Berdasarkan hasil perhitungan diperoleh nilai koefisien regresi untuk nilai $\mathrm{X}$ yaitu 0, 649; artinya apabila Kepemimpinan meningkat sebesar 1 satuan maka Kinerja pada Reserse Polresta Pekanbaru akan meningkat sebesar 0, 649 satuan. Dari persamaan regresi diatas menunjukkan koefisien regresi dari variabel independent yaitu $\mathrm{b}$ bertanda positif (+), maka dimana dalam hal ini berarti variabel Kepemimpinan (X) berpengaruh terhadap Kinerja Reserse Polresta Pekanbaru.

Dapat kita lihat tingkat korelasi yaitu sebesar 0,670 atau 67,0\%, ini menunjukkan bahwa tingkat hubungan antara variabel independent terhadap variabel dependentnya. Berdasarkan standar kategori Guilford pengaruh Kepemimpinan Terhadap Kinerja Reserse Polresta Pekanbaru adalah hubungan tinggi atau pengaruh kuat. Ini dapat dilihat pada kriteria derajat hubungan koefisien korelasi yaitu $0,70-0,90$ adalah tingkat hubungan sedang atau pengaruh sedang.

\begin{tabular}{|c|c|c|c|}
\hline Variabel & t-hitung & t-Tabel & Probabilitas \\
\hline Kepemimpinan & 8.365 & 1,999 & 0,000 \\
\hline
\end{tabular}

Sumber:Hasil Olahan SPSS

Uji $t$ merupakan pengujian hipotesis tentang parameter koefisien regresi yang bertujuan untuk mengetahui apakah variabel $\mathrm{X}$ mempunyai pengaruh yang nyata terhadap variabel $\mathrm{Y}$ dengan level signifikan $5 \%$ atau 0,05 dengan ketentuan sebagai berikut :

1. Jika thitung $>t_{T}$ abel maka variabel bebas mempunyai pengaruh yang signifikan terhadap variabel terikat (Ho ditolak, Ha diterima).

2. Jika $t_{\text {hitung }}<\mathrm{t}_{\text {Tabel }}$ maka variabel bebas tidak mempunyai pengaruh yang signifikan terhadap variabel terikat (Ho diterima, Ha ditolak).

Hasil perhitungan regresi memperlihatkan bahwa Kepemimpinan memiliki thitung yang lebih besar dari tTabel yaitu $8.365>1,999$ yang berarti Ho ditolak dengan demikian Ha diterima. Artinya variabel Kepemimpinan mempunyai pengaruh yang signifikan terhadap Kinerja pada Reserse Polresta Pekanbaru.
Dari

analisis diatas dapat disimpulkan bahwa hipotesis yang menyatakan bahwa Kepemimpinan mempunyai pengaruh yang positif dan signifikan terhadap Kinerja pada Reserse Polresta Pekanbaru.

Uji ini dilakukan untuk melihat seberapa besar persentase sumbangan variabel Kepemimpinan Terhadap Kinerja Anggota. Pengukurannya adalah dengan menghitung angka koefisien determinasi $\left(\mathrm{r}^{2}\right)$. Semakin besar nilai koefisien determinasi (mendekati satu) maka semakin tepat suatu garis linear digunakan sebagai suatu pendekatan hasil penelitian.

Berdasarkan hasil penelitian diperoleh nilai $\mathbf{r}^{2}$ sebesar 0,449 Artinya $44,9 \%$ variabel Kinerja pada Reserse Polresta Pekanbaru dipengaruhi oleh Kepemimpinan, sedangkan 55,1 \% dipengaruhi oleh faktor- faktor lain yang tidak diteliti dalam penelitian ini.

\section{PEMBAHASAN}

Dari analisa seperti yang telah diuraikan sebelumnya dapat dilihat bahwa Kepemimpinan mempunyai pengaruh yang signifikan terhadap Kinerja pada Reserse Polresta Pekanbaru. Kepemimpinan yang baik sangat dibutuhkan Reserse Polresta Pekanbaru untuk dapat meningkatkan kinerja.

Berdasarkan hasil perhitungan diperoleh nilai koefisien regresi untuk nilai $X$ yaitu 0,649 artinya apabila Kepemimpinan meningkat 1 satuan maka Kinerja pada Reserse Polresta Pekanbaru akan meningkat sebesar 0, 649 satuan. Dari persamaan regresi diatas menunjukkan koefisien regresi dari variabel independen yaitu $b$ bertanda positif $(\mathrm{X})$, dimana dalam hal ini variabel Kepemimpinan (X) berpengaruh Terhadap Kinerja pada Reserse Polresta Pekanbaru.

Untuk meningkatkan Kinerja

Reserse Polresta Pekanbaru Reserse Polresta Pekanbaru dapat dilakukan dengan memperbagus lagi sistem Kepemimpinan agar lebih efektif sehingga Kepemimpinan yang diberikan perusahaan dapat lebih 
berguna terhadap Kinerja pada Reserse Polresta Pekanbaru, juga harus dapat menerapkan atau memenuhi faktor- faktor lainnya seperti koordinasi yang tepat, pengawasan, rasa aman menghadapi masa depan, promosi, komunikasi. Sehingga Anggota dapat meningkatkan usahanya menjadi lebih baik dan juga dapat mengembangkannya demi terciptanya lapangan kerja baru.

Uang sebagai penghargaan dan insentif, menyebutkan persyaratannya, mengembangkan keterikatan, memotivasi melalui pekerjaan itu sendiri, menghargai dan mengakui prestasi kerja, mengembangkan kepemimpinan, membangun kerjasama antar kelompok, melatih dan mengembangkan setiap orang, serta menghilangkan hal-hal yang negatif. (Rahmat, 2016)

\section{SIMPULAN}

Berdasarkan hasil penelitian dan pembahasan serta analisa yang dilakukan pada bab sebelumnya, maka penulis menarik kesimpulan sebagai berikut: Kepemimpinan yang diberikan tiap tahunnya yaitu, Upaya membangun tim kerja yang solid, Upaya mengelola konflik, Upaya mencari informasi yang dapat mempelancar segala aktivitas kerja, Kemauan \& kemampuan memutuskan pemecahan masalah dan Kemampuan meKepemimpinan kerja karyawan. Dalam penelitian ini terlihat bahwa Kepemimpinan yang telah diberikan sudah cukup baik namun masih perlu ditingkatkan lagi agar kinerja yang diharapkan dapat meningkat. Artinya semakin baik Kepemimpinan maka semakin baik pula Kinerja Reserse Polresta Pekanbaru.

Kinerja pada Reserse Polresta Pekanbaru adalah cukup baik. Sehingga tingkat pencapaian hasil mendekati sempurna, cara bekerja sesuai dengan cara ideal, memenuhi tujuan yang diharapkan, jumlah yang dihasilkan memenuhi target dan memaksimalkan waktu yang tersedia untuk aktivitas yang lain. Berarti Kinerja Anggota yang sudah cukup baik ini perlu ditingkatkan lagi menjadi sangat baik.
Kepemimpinan berpengaruh signifikan terhadap Kinerja Anggota Reserse Polresta Pekanbaru. Besar pengaruh variabel Kepemimpinan terhadap Kinerja Anggota Reserse Polresta Pekanbaru.

\section{DAFTAR RUJUKAN}

Arikunto, Suharsimi. 2006. Prosedur Penelitian Suatu Pendekatan Praktik. Jakarta :Rineka Cipta.

Fuad, Noor dan Ahmad, Gofur. 2009. Integreted Human Resources Development. Jakarta: PT Grasindo 18

Gozali, Iman, 2005, Aplikasi Analisis Multivariat Dengan Program SPSS, BP UNDIP, Semarang

Hasibuan, Malayu S.P., (2006), Manajemen Sumber Daya Manusia, Edisi Revisi Cetakan Ke-8, PT. Bumi Aksara, Jakarta

Hardjana, Agus M, (2003), Komunikasi Intrapersonal dan Interpersonal, Yogyakarta, Penerbit Kanisius

Istijanto. 2005. Riset Sumber Daya Manusia. Jakarta : Kampus IPB Taman Kencana Bogor : IPB Press.

Isyandi, B (2004), Manajemen Sumber Daya Manusia, Pekanbaru, UNRI Press

Luthans, Fred. 2006. Perilaku Organisasi Edisi Sepuluh. Yogyakarta : ANDI.

Mangkunegara, Anwar Prabu. 2009. Manajemen Sumber Daya Manusia Perusahaan. Bandung : PT Remaja Rosdakarya

Mangkuprawira, Tb Sjafri. 2009. Bisnis, Manajemen, dan Sumber Daya 
Manusia. Bogor : IPB Press Kampus IPB Taman Kencana Bogor

Manopo, Christine. 2011. Competency Based Talent and Performance Management System. Jakarta : Salemba Empat.

Mahmudi, 2005, Manajemen Kinerja Sektor Publik, Unit Penerbit Akademi Manajemen Perusahaan YPKN, Yogyakarta.

Machasin \& Andreas. 2005. Reformasi Kepemimpinan Birokrasi Pemerintah; Antara Idealisme dan Realitas. Lingkaran. Yogyakarta.

Mathis, Robert L dan John H Jackson, 2006, Human Resource Management, terjemahan, Edisi Kesepuluh, Jakarta, Salemba Empat.

Nurmasyah SR, 2007, Manajemen Sumber Daya Manusia, UNILAK Press, Pekanbaru

Pasolong, Harbani. (2010). Kepemimpinan Birokrasi. Bandung: Alfabeta.

Rahmat, A. (2016) 'Pengaruh Faktor-faktor yang Mempengaruhi Motivasi Terhadap Kinerja Karyawan (Survey Pada Bank Riau Kepri Cabang Tanjung Balai Karimun)'. pekanbaru: jurnal daya saing vol 2 no 2 , pp. 9199.

Rivai, Veithzal, 2004, Kepemimpinan dan Perilaku Organisasi, PT. Raja Grafindo Persada, Jakarta.

Rivai, Veithzal dan Fawzi, Ahmad. 2005. Performance Appraisal. Jakarta : PT Raja Grafindo Persada , 2003, Manajemen Sumber Daya Manusia Untuk Perusahaan, PT. Rajagrafindo Persada, Jakarta.

Rivai, Veithzal dan Mulyadi, Deddy. 2009, Kepemimpinan dan Perilaku
Organisasi, Edisi Kedua. PT. Raja Grafindo Persada, Jakarta.

Robbins, Stephen P, (2006), Prilaku Organisasi, Management, New Jersey, Penerbit Prentice Hall Inc

Sarjono, Haryadi dan Julianita, Winda. (2011). SPSS vs LISREL sebuah pengantar, aplikasi untuk riset. Salemba Empat, Jakarta.

Siagian, Sondang P. 2003. Teori \& Praktek Kepemimpinan. Cet.5. Rineka Cipta. Jakarta.

Suliyanto. 2006. Metode Riset Bisnis. Yogyakarta: Andi

Sutrisno, Edy. 2009. Manajemen Sumber Daya Manusia. Edisi Pertama, Cetakan Pertama, Penerbit Kencana, Jakarta.

Sutrisno, Edy. 2010. Budaya Organisasi. Edisi Pertama, Cetakan ke-2, Penerbit Kencana, Jakarta.

Sugiyono. 2007. Statistika Untuk Penelitian. Bandung : Alfabeta.

ThohaMiftah. 2006. Kepemimpinan dalam Manajemen. PT. Raja Grafindo Persada : Jakarta.

2007. PerilakuOrganisasi, KonsepDasardanAplikasinya. PT. RajaGrafindoPersada : Jakarta

Wibowo, 2007, Manajemen Kinerja, PT. Rajagrafindo Persada, Jakarta.

Wibowo (2011). Budaya Organisasi. Sebuah Kebutuhan Untuk Meningkatkan Kinerja Jangka Panjang. Rajawali Pers. Jakarta 